\title{
Nutritional assessment of silage from transgenic inulin synthesizing potatoes for pigs
}

\author{
H. Böhme ${ }^{1,3}$, B. Hommel ${ }^{2}$ and G. Flachowsky ${ }^{1}$ \\ ${ }^{1}$ Institute of Animal Nutrition, Federal Agricultural Research Centre (FAL) \\ Bundesallee 50, D-38116 Braunschweig, Germany \\ ${ }^{2}$ Institute for Integrated Plant Protection, \\ Federal Biological Research, Centre for Agriculture and Forestry (BBA) \\ Stahnsdorfer Damm 81, D-14532 Kleinmachnow, Germany
}

\begin{abstract}
To evaluate silage from transgenic inulin synthesizing potatoes as compared to that from the parental cultivar, nutrients and undesirable substances were analysed and their digestibility and production potential were studied. The content of starch decreased (60 vs 67\% in DM), and the total alkaloids in fresh potatoes increased ( $904 \mathrm{vs} 728 \mathrm{mg} \mathrm{mg} / \mathrm{kg} \mathrm{DM}$ ). The digestibility of the fibre fraction decreased ( 73 vs $81 \%$ ), which was almost compensated by an improved NfE-digestibility. The energetic feeding value was 14.3 and $14.6 \mathrm{MJ} \mathrm{ME} / \mathrm{kg} \mathrm{DM}$ for the silage of transgenic or isogenic potatoes, respectively. These results were confirmed in a feeding test over 42 days. Average daily liveweight gain of the pigs fed the transgenic silage was $43 \mathrm{~g}$ lower than the controls.
\end{abstract}

KEY WORDS: potato, genetic modification, inulin, feeding value, pig

\section{INTRODUCTION}

Nutritional assessment studies for genetically modified plants of the first generation with manipulations which only refer to cultivation traits are numerous (Flachowsky et al., 2005). In the future, transgenic plants with substantial changes in their composition will gain more importance and there is a need to assess their nutritional value.

The ability to synthesize high molecular weight fructan as inulin was transferred to potato plants via constitutive expression of the 1-SST (sucrose:sucrose 1-fructosyltransferase) and the 1-FFT (fructan:fructan 1-fructosyltransferase) genes of globe artichoke, Cynara scolymus (Heyer et al., 1999). As the fructan pattern of tubers from this transgenic potato plant represents the full inulin spectrum of artichoke roots, they are intended to be used as a prebiotic functional food in human nutrition. The inulin concentration in the dry matter of the transgenic tubers amounts to $5 \%$ (Hellwege et al., 2000). The objective of this study was to analyse the extent to which this modification influences the content of key feed nutrients, their availability to pigs as a model for monogastrics, and the concentration of antinutritional substances.

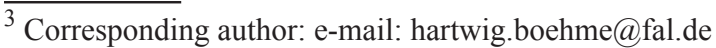




\section{MATERIAL AND METHODS}

The three transgenic potato lines and the non-transformed isogenic line (i.e. cv. Désirée) used as counterpart were grown under the same field conditions at the experimental station of the Biological Research Centre (BBA) in Kleinmachnow from April to September, 2003. The tubers were steamed after harvesting and ensilaged in 2001 plastic silos, those of the transgenic lines were pooled. The silages were used for feeding experiments after a 5-month period. The official VDLUFA-methods were applied to analyse the chemical composition and apparent digestibility were estimated according to Naumann and Bassler (1999). The nutritive value of both variants was determined in balance experiments with pigs according to the GfE (2005). Additionally, a feeding test lasting 42 days was conducted. The basal diet contained, \%: wheat 37 , barley 32 and potato protein concentrate 18 , providing $25.2 \% \mathrm{CP}$ and $15.5 \mathrm{MJ} \mathrm{ME} / \mathrm{kg}$ DM. In the experimental diets $40 \%$ of the DM was replaced by potato silage. The diets were tested on castrates of German hybrids. The energy supply amounted to 2.3 times the maintenance requirements. The collection period of faeces lasted 10 days. In the subsequent feeding trial, the pigs were fed semi ad libitum with the experimental rations. To test the differences in digestibility and feeding value between variants, the Student-Newman-Keuls' test was chosen applying a confidence level of $0.95 \%$.

\section{RESULTS AND DISCUSSION}

The growing season in northeast Germany in 2003 was the dryest and the hottest in decades. Rainfall from May to August was only $130 \mathrm{~mm}$ at the experimental site, so the yields of potatoes did not exceed $30 \mathrm{t} / \mathrm{ha}$.

The content of crude nutrients and minerals in silages of both potato variants is summarized in Tables 1 and 2. Proximates and mineral contents do not show significant differences due to the genetic manipulation, but the starch content decreased, which is in accordance with the result from fresh tubers (13.4 vs $15.0 \%$ ). This indicates that the inulin synthesis is limited and does not increase the storage capacity of carbohydrates (Hellwege et al., 2000).

Table 1. Crude nutrients, starch and sugar in silage from transgenic inulin synthesising potatoes as compared to those of the parental line, $\%$ of DM

\begin{tabular}{lcccccccc}
\hline & DM & OM & CP & EE & CF & NFE & Starch & Sugar \\
\hline Transgenic & 19.5 & 94.2 & 10.6 & 0.6 & 2.8 & 80.2 & 59.9 & - \\
Isogenic & 21.2 & 94.5 & 10.7 & 0.6 & 2.5 & 80.7 & 67.4 & - \\
\hline
\end{tabular}

Table 2. The content of macro elements of silage from transgenic inulin synthesising potatoes as compared to those of the parental line, $\mathrm{g} / \mathrm{kg} \mathrm{DM}$

\begin{tabular}{lccccc}
\hline & $\mathrm{Ca}$ & $\mathrm{P}$ & $\mathrm{K}$ & $\mathrm{Na}$ & $\mathrm{Mg}$ \\
\hline Transgenic & 0.56 & 2.20 & 20.00 & 0.23 & 0.84 \\
Isogenic & 0.51 & 2.10 & 19.60 & 0.30 & 0.90 \\
\hline
\end{tabular}


The amino acid profile of the trans- and isogenic potato protein was determined to study any effect of the genetic modification on protein composition. The results show that no meaningful significant differences in the levels of any of the 16 amino acids measured were found. The concentrations of the first-limiting amino acids are given in Table 3.

Table 3. Amino acid analysis of the protein of transgenic inulin synthesising potatoes as compared to that of the parental line, $\mathrm{g}$ amino acid/100 $\mathrm{g}$ crude protein

\begin{tabular}{lcc}
\hline Amino acid & Transgenic & Isogenic \\
\hline Lysine & 4.00 & 4.31 \\
Methionine & 1.39 & 1.18 \\
Cystine & 0.87 & 0.95 \\
Threonine & 2.53 & 2.49 \\
\hline
\end{tabular}

The undesirable substances referred to as glycoalkaloids were analysed in the fresh material freeze-dried but not ensilaged. Total alkaloid content of the transgenic tubers was about $25 \%$ higher than that of the isogenic potatoes (Table 4 ). This is found for $\alpha$-chaconine and $\alpha$-solanine as well. Interpretations of these data should consider that draught stress increases generally the glycoalkaloid content in potato tubers (Friedman and McDonald, 1997). The results confirm that substantial genetic modifications might be associated with increased concentrations of undesirable substances, but in this case they do not reach the safety limit, which is widely accepted to be $200 \mathrm{mg}$ total glycoalkaloids per $\mathrm{kg}$ tuber fresh weight corresponding to appr. $1 \mathrm{~g} / \mathrm{kg} \mathrm{DM}$.

Table 4. Glycoalkaloid content of trans- and isogenic potato tubers, $\mathrm{mg} / \mathrm{kg} \mathrm{DM}$

\begin{tabular}{lccc}
\hline Potatoes & $\alpha$-Chaconine & $\alpha$-Solanine & Total alkaloids \\
\hline Transgenic & 652 & 252 & 904 \\
Isogenic & 524 & 204 & 728 \\
\hline
\end{tabular}

Although high amounts of feedstuffs under study were incorporated in the rations, the health and behaviour of the pigs were not affected. The results on apparent digestibility are given in Table 5 . As far as the digestibility of the various

Table 5. Digestibility and energetic feeding value of inulin synthesising potatoes as compared to those of the non-transgenic controls (means \pm SD)

\begin{tabular}{lccc}
\hline \multirow{2}{*}{ Nutrients } & \multicolumn{3}{c}{ Digestibility of nutrients, \% } \\
\cline { 2 - 4 } Organic matter & $93.2 \pm 1.2$ & isogenic & $\mathrm{P}$ \\
Crude protein & $73.0 \pm 10.5$ & $76.9 \pm 1.5$ & 0.54 \\
Ether extract & $49.9 \pm 19.3$ & $66.3 \pm 16.5$ & 0.60 \\
Crude fibre & $72.6 \pm 11.8$ & $81.0 \pm 6.1$ & 0.33 \\
N-free extractives & $94.2 \pm 4.3$ & $90.7 \pm 7.1$ & 0.27 \\
MJ ME/kg DM & $14.34 \pm 0.21$ & $14.60 \pm 0.90$ & 0.49 \\
\hline
\end{tabular}

nutrients is concerned, significant differences were not calculated although the CF-digestibility seemed to be depressed and the NfE-digestibility increased. 
However, the energetic feeding value, which was calculated based on digestible nutrients (GfE, 1987), was only slightly affected.

Although not significant, the lower production potential of the silage from the transgenic potatoes due to the lower starch content was also confirmed in feeding test.

For a period of 42 days, both groups were fed the same amounts of the concentrate and potato silage, but while feeding the transgenic silage the MEintake was $0.9 \mathrm{MJ} / \mathrm{d}$ lower, resulting in a lower growth performance. The average daily liveweight gain of the pigs fed transgenic silage was $43 \mathrm{~g}$ lower during this period as compared to controls.

\section{CONCLUSIONS}

Proximate analyses and digestibility investigations indicate that the genetic transformation of inulin synthesis in potatoes results in depressions of starch content and fibre digestibility, what is almost compensated by an improved NfEdigestibility. From the energetic point of view, this modification has to be regarded as a disadvantage in feeding pigs but an advantage for human nutrition. Whether these transgenic potatoes have the ability to act as prebiotics influencing the microflora in the digestive tract favourably will be the subject of further investigations.

\section{REFERENCES}

Flachowsky G., Chesson A., Aulrich K., 2005. Animal nutrition with feeds from genetically modified plants. Arch. Anim. Nutr. 59, 1-40

Friedman M., McDonald G.M., 1997. Potato glycoalkaloids: Chemistry, analysis, safety, and plant physiology. Crit. Rev. Plant Sci. 16, 55-132

Gesellschaft für Ernährungsphysiologie (GfE), Ausschuß für Bedarfsnormen, 1987. Energie- und Nährstoffbedarf landwirtschaftlicher Nutztiere. Nr. 4, Schweine. DLG-Verlag, Frankfurt (Main)

Gesellschaft für Ernährungsphysiologie (GfE), Ausschuß für Bedarfsnormen, 2005. Determination of digestibility as the basis for energy evaluation of feedstuffs for pigs. Proc. Soc. Physiol. 14, 207-213

Hellwege E.M., Czapla S., Jahnke A., Willmitzer L., Heyer A.G., 2000. Transgenic potato (Solanum tuberosum) tubers synthesize the full spectrum of inulin molecules naturally occurring in globe artichoke (Cynara scolymus) roots. Proc. Nat. Acad. Sci. USA 97, 8699-8704

Heyer A.G., Lloyd J.R., Kossmann J., 1999. Production of modified polymeric carbohydrates. Curr. Opin. Biotechnol. 10, 169-174

Naumann C., Bassler R., 1993. Die chemische Untersuchung von Futtermitteln. VDLUFA-Verlag, Darmstadt

\section{STRESZCZENIE}

\section{Ocena wartości pokarmowej kiszonki z transgenicznych, syntetyzujących inulinę, ziemniaków} dla świń

Zawartość skrobi w ziemniakach transgenicznych oraz strawność włókna i wartość energetyczna kiszonek z ziemniaków transgenicznych były mniejsze niż z ziemniaków zwykłych. 